\title{
A Citizen Science Initiative to Understand Community Response to the Kaikōura Earthquake and Tsunami Warning in Petone and Eastbourne, Wellington, Aotearoa/New Zealand
}

\author{
by Denise Blake, David Johnston, Graham Leonard, Lisa McLaren, and Julia Becker
}

\begin{abstract}
On the 14 November 2016, an M 7.8 earthquake occurred in the northeast of the South Island of Aotearoa/New Zealand, causing damage to homes and disrupting critical infrastructure. The earthquake produced a local-source tsunami that impacted the east coast of the South and North Islands, with the first wave (of a few centimeters height) arriving in the Wellington region within $30 \mathrm{~min}$. The largest waves in Wellington arrived between 1 and $5 \mathrm{hrs}$ after the initial wave and were $\sim 60 \mathrm{~cm}$ in height. Initially, an official "no tsunami threat" message was issued based on scientific interpretation directly following the earthquakes. Scientific advice from Aotearoa/New Zealand (supported by overseas) suggested there was not a tsunami threat. Approximately $1 \mathrm{hr}$ later, this was revised to an official warning stating, "Tsunami threat to Aotearoa/New Zealand" based on updated scientific advice (primarily tide gauge readings), and many communities needed to evacuate, including Petone and Eastbourne in the Hutt Valley, Wellington region, Aotearoa/New Zealand. Approximately three and a half weeks after the earthquake, a survey was undertaken with Petone and Eastbourne residents using a citizen science approach to understand tsunami response and evacuation behaviors. A total of 409 surveys were collected, with 245 respondents from Petone and 164 from Eastbourne. Results established the majority of total respondents evacuated (69\%), but only $33 \%$ evacuated within the 10-min natural warning evacuation threshold recommended for local-source tsunamis. This was despite most respondents saying that the earthquake felt longer than $1 \mathrm{~min}(64 \%)$ and was strong to severe (70\%). Only $11 \%$ evacuated because of the earthquake. Most (64\%) respondents used vehicles to evacuate, causing prohibitive traffic congestion during the evacuation. The results emphasize the need to engage communities to enhance capacity to respond appropriately to both natural and agency-generated tsunami warnings to ensure community safety and wellbeing in tsunami events.
\end{abstract}

\section{Introduction}

Aotearoa/New Zealand lives under constant threat of distant-, regional-, and local-source tsunami $(<1,1-3$, and $>3 \mathrm{hrs}$ of travel time from the nearest New Zealand coast, respectively) which can cause significant harm to people and the environment. The Wellington region, which incorporates the Hutt Valley, is recognized as one of four high-risk tsunami coastal regions because it is adjacent to the Hikurangi subduction zone on the east coast of Aotearoa/New Zealand (Power, 2013; Gill et al., 2015; Horspool et al., 2015). A local-sourced ( $<1 \mathrm{hr}$ away from the nearest coast) tsunami triggered by the Hikurangi subduction zone could cause a tsunami to strike the Hutt Valley within minutes (Power, 2013). In this instance, the only possible warnings of the potential tsunami in 2016 were natural, specifically, the earthquake ground shaking. Warnings were and will continue to be issued with future events as soon as possible (during subsequent waves) to reinforce evacuation behavior. The Hutt Valley could also be impacted by a tsunami generated by distant ( $>3$ hrs travel time away) and regional (1-3 hrs away) sources, which would allow some official warning of potential tsunami. To advance knowledge and gain insight into preparedness and evacuation behavior, this article focuses on the preparedness and tsunami evacuation behavior of people living in the Petone and Eastbourne suburbs of the Hutt Valley after the 2016 Kaikōura earthquake. 
The 14 November 2016 Kaikōura Earthquake and Tsunami

On 14 November 2016, an M 7.8 earthquake struck near the coast of Kaikoura on the northeast coast of the South Island. Initially, an official "no tsunami threat" message was issued by the Aotearoa/New Zealand's Ministry of Civil Defence and Emergency Management (MCDEM) based on scientific interpretation possible in the first minutes after the earthquakes. Scientific advice from within Aotearoa/ New Zealand, supported by overseas data, suggested there was not a tsunami threat to Aotearoa/New Zealand. However, when the tsunami was noticed on the Kaikoura tide gauge, a tsunami threat was identified for coastal areas of Aotearoa/ New Zealand, including the Hutt Valley and the wider Wellington region. This earthquake caused widespread damage to homes, transport networks, and lifeline utilities in many areas of the upper South and southern North Islands (Woods et al., 2017). The earthquake event was complex because its epicenter was $\sim 80 \mathrm{~km}$ inland from the coast, and there were at least 21 surface fault ruptures, with four of those ruptures offshore.

The event triggered the largest tsunami sourced from close to Aotearoa/New Zealand's shoreline since the 1947 tsunami near the town of Gisborne in the North Island of Aotearoa/New Zealand (Bell et al., 2014). The Kaikōura tsunami runup affected $\sim 200 \mathrm{~km}$ of the northeast of the South Island. Although the tsunami had an estimated wave height of 1-5 m near source, it had a moderate coastal impact because of the substantial coastal uplift (meters) near the source, low tide, and steep topography of the northeast coast of the South Island (Power et al., 2017).

The earthquake started at 12:02 a.m. and lasted for nearly $2 \mathrm{~min}$. It was widely felt throughout the South and North Islands, including the Wellington region. The initial tsunami wave was visible within minutes on the Kaikoura tide gauge (more visible after back-correcting for coastal uplift) and was noticeable (a few centimeters peak to trough) in the Wellington gauge records within $30 \mathrm{~min}$ (Power et al., 2017). More substantial waves of almost $60 \mathrm{~cm}$ were recorded in Wellington from around 1:10 hrs after the earthquake, and these waves lasted for $4 \mathrm{hrs}$.

After the tsunami threat was officially detected and evaluated, a warning was issued by MCDEM (01:00 a.m. -a National Warning: Tsunami threat) to all southern coastal areas of Aotearoa/New Zealand. The Hutt Valley suburbs of Petone and Eastbourne received formal notification of a tsunami threat at 01:25 a.m. after the threat area was expanded (MCDEM's Twitter and Facebook accounts were updated at 01:21 a.m.). Emergency management officials deemed widespread evacuation necessary in Petone and Eastbourne, and subsequent communication about tsunami evacuation was disseminated via media and social media messages and by sounding the Hutt Civil Defence and Emergency Management (CDEM) flood siren. This further dissemination of the warnings by public channels (television and radio) was undertaken in response to the official warning from MCDEM. However, the sirens are operated by the local CDEM authority-Wellington Region Emergency Management Office (WREMO). Both MCDEM and WREMO used social media to communicate to the public.

An initial "no threat" message on WREMO's Facebook page at 12:46 a.m. (reposted at 1:10 am on the Hutt City Council webpage) was superseded by a threat message at 1:34 a.m., also on the WREMO Facebook page. This message instructed people to move inland or to high ground. A further message at 1:50 a.m. reported that the situation was evolving and that people should stay off at least the beaches and the tidal estuary areas. A further message at 2:30 a.m. stated that the Red Zone (effectively beaches and marine) should remain evacuated. The Hutt city sirens were activated during this period, and their deactivation was signaled by a post on their Facebook page at 2:36 a.m. stating that the "sirens are now off." All tsunami warnings were canceled by MCDEM at 3 p.m.

The MCDEM (2017a) provide a summary of the timeline (see their section 4.2) of national events on the day and subsequent updates to their procedures. The following quote explains the warnings and decision making in the critical $2 \mathrm{hrs}$ after the earthquake (MCDEM, 2017a, p. 10):

Following consultation with GNS [Science] and noting the statement from the Pacific Tsunami Warning Centre (PTWC) a National Advisory: No Tsunami Threat message was issued at 0040 NZDT. At the same time the National Advisory: No Tsunami Threat message was issued, the GNS Duty Officer observed a drop in the tide gauge at Kaikoura which indicated that a tsunami had been generated. Based on this information and the advice of GNS, the [MCDEM] Duty Team then issued a National Warning: Tsunami Threat for all southern coastal areas at 0100 NZDT via the NZFS [New Zealand Fire Service]. At 0125 MCDEM sent out another National Warning: Tsunami Threat for the eastern coast of North and South Island including the Chatham Islands.

\section{Warnings, Evacuation, and Human Behavior}

To understand the context within which people from the Hutt Valley responded to the Kaikōura tsunami event, it is necessary to reflect on previous research on warnings, evacuation, and human behavior. Throughout the world, research into tsunami warnings and evacuation behaviors has demonstrated the biological, psychological, social, and environmental complexity of people's responses (see e.g., Gregg et al., 2006; Bird et al., 2011; Ullah, 2011; Lindell et al., 2015; Fraser et al., 2016). A recent focus has been on understanding the impact of, and public response to, the Japan Tsunami of 2011 (Suzuki and Kaneko, 2013; Fraser et al., 2016), when many witnessed a multitude of televised and online recordings of the devastation unfold.

Research specifically focusing on tsunami that effect Aotearoa/New Zealand includes the work of Johnston et al. 
(2008), who explored the historical impact of the 1960 M 9.5 Chilean earthquake. Without a Pacific-wide warning system operating at the time, the tsunami caused widespread coastal damage but, fortunately, no fatalities. However, after a subsequent earthquake three days later, a nationwide tsunami alert was called, and the largest evacuation in Aotearoa/ New Zealand's history occurred. At the time, officials realized that it was necessary to address the lack of a tsunami warning system and increase public education about preparedness planning to improve evacuation and preparedness behavior. Johnston et al. (2008) identified that over the next $40 \mathrm{yrs}$, interest in tsunami warnings and evacuation behavior waned. It was not until the 2004 Indian Ocean tsunami that Aotearoa/New Zealand modified its emergency management policies and practices with the goal of improving responses during a tsunami event.

A national coastal survey was conducted by Johnston et al. (2003) that aimed to understand tsunami preparedness behavior and awareness in 42 locations throughout Aotearoa/ New Zealand. The research found that public education about tsunami was minimal and varied among regions, and overall public awareness was low.

Subsequent studies building on the Johnston et al. study have demonstrated that tsunami awareness has increased since 2003 (see e.g., Couling, 2013; Currie et al., 2014). Dhellemmes et al. (2016) surveyed the same 10 communities as Johnston et al. (2003) and found that awareness about appropriate warning-response actions had grown for people living in coastal areas but that tsunami preparedness and understanding of warning messages were mixed. Many respondents expected to receive formal tsunami warnings even with local tsunami events that provide little warning time. Respondents' evacuation intentions showed that many intended to undertake certain actions after an earthquake (e.g., find pets or fetch children from school), which could be time consuming and cause unsafe delays in evacuation. Most people reported that they preferred to evacuate using vehicles rather than on foot. It was noted that evacuation actions and procedures were misunderstood by the public.

A further study by Fraser et al. (2016) investigated people's behaviors after two earthquakes that occurred $80 \mathrm{~km}$ from Wellington, Aotearoa/New Zealand in 2013 (M 6.5 Cook Strait earthquake; M 6.6 Lake Grassmere earthquake). Surveying a coastal suburb of Wellington, it was found that although people overestimated the intensity and duration of the earthquakes, they widely failed to evacuate. This coastal community had received tsunami risk education and had participated in evacuation mapping; however, this did not adequately influence people's perceptions of a tsunami threat.

Noticeably, the previous research demonstrated the necessity of continued research into tsunami evacuation behavior to better understand human responses to tsunami warnings, especially after an actual event. The 2016 Kaikōura earthquake and tsunami provided a good context to do just this. Research teams were engaged to undertake a survey on people's responses to the Kaikōura earthquake and tsunami at various locations along the east coast of Aotearoa/New Zealand. Survey questions were modeled on the set of questions used by Dhellemmes et al. (2016) and aimed to gather people's reactions to the earthquake, including information on evacuation behavior, what people took with them if they did evacuate, how long it took to evacuate, where people went when they evacuated, and why they eventually returned home. This article presents a case study based on the survey responses from Petone and Eastbourne areas of the Hutt Valley. Data were collected during an eight-day period in December 2016, approximately three and a half weeks after an M 7.8 Kaikōura earthquake and tsunami evacuation.

\section{Petone and Eastbourne: A Tsunami Evacuation Context}

Petone and Eastbourne are coastal suburbs in the Hutt Valley that are exposed to a range of hazards, including coastal erosion, flooding, inundation, and tsunami (Wellington City Council, 2017). The entire coastal Wellington region of Aotearoa/New Zealand, of which Petone and Eastbourne are part, is at risk from distant, regional, and local-source tsunami. Locally generated near-field tsunami poses the largest wave-height threat and can be generated through activity in the Hikurangi subduction margin of the Pacific-Australia Plate Boundary that runs along the southeast coast of Aotearoa/New Zealand and Cook Strait fault ruptures or Cook Straight submarine landslides (GNS Science Te Pū Ao, 2017; see Data and Resources; Wellington City Council, 2017).

For this research, the Petone area covered the Hutt Valley suburbs of Petone Central, Petone Esplanade, Alicetown, Wilford, and Moera. The total population of the combined Petone area is $\sim 8300$. Petone has an average median personal income of $\$ 32,000$ U.S., with a total of 3306 households. The suburb of Eastbourne has 4600 residents, with an average median personal income of $\$ 42,200$ U.S. The number of households in Eastbourne is 1845 (Statistics New Zealand, 2013; see Data and Resources).

As depicted in Figure 1, the two communities have a contrasting geographical setting with Petone sitting solely on a flood plain bounded (and confined in terms of evacuation) by the Hutt River to the east and two significant transport corridors to the northwest- the Hutt Valley rail line and State Highway 2. Ten bridges provide the only egress from the area. The Eastbourne area is situated on a narrow coast flat with high ground immediately behind it. The immediate high ground in close proximity for Eastbourne residents affords significantly less travel time for evacuation than those in Petone.

Both suburbs have existing tsunami evacuation maps, developed as per national guidelines (MCDEM, 2016). A series of blue lines are also painted across all roads at the landward extent of the largest evacuation zone to assist people with knowing how far to evacuate (Johnston et al., 2013). 


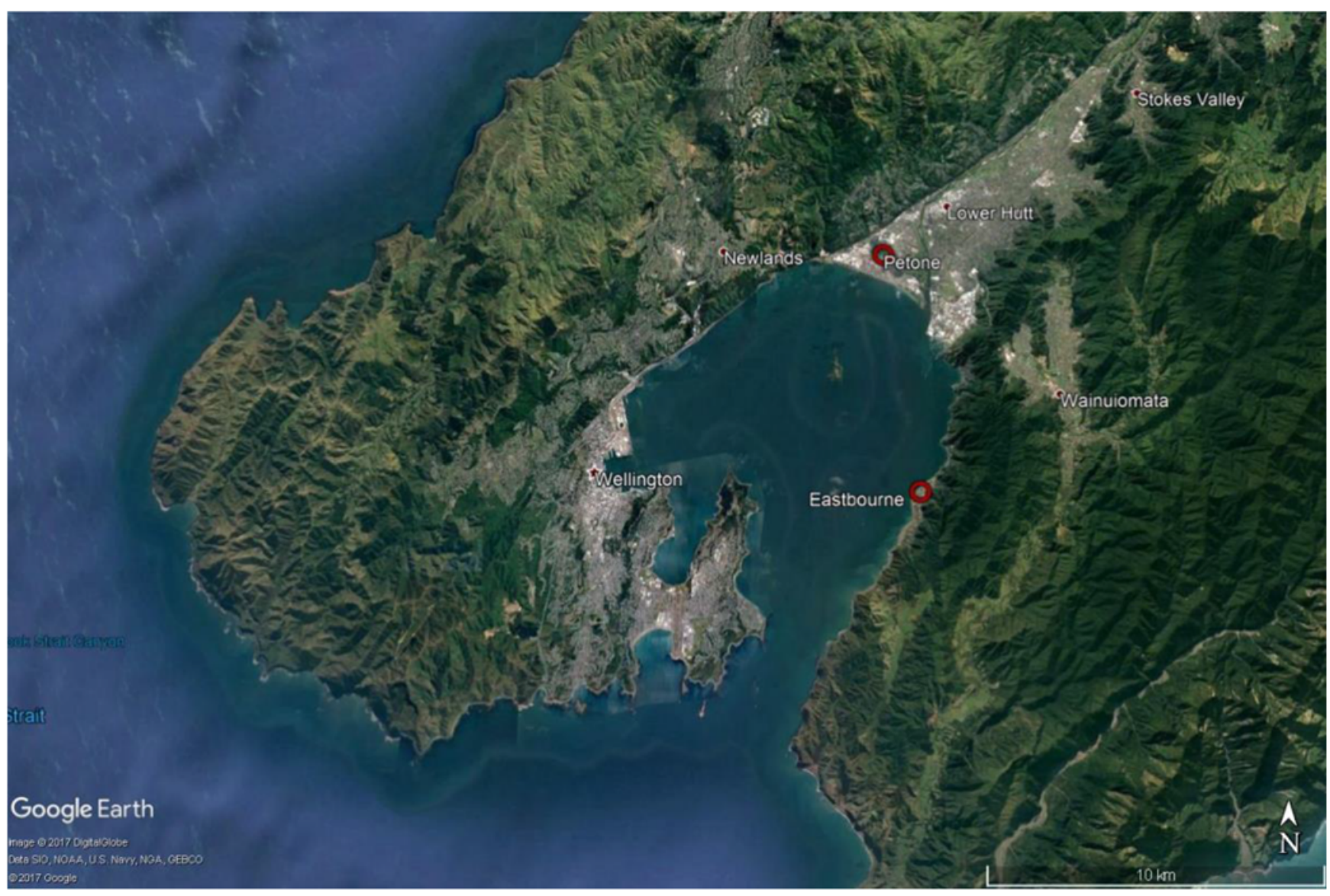

Figure 1. Map of Petone and Eastbourne in the Hutt Valley region. The color version of this figure is available only in the electronic edition.

\section{Petone and Eastbourne within the National Warning Context}

The national tsunami advisory warning plan (MCDEM, 2017b) describes arrangements for receipt and interpretation of PTWC warning messages for tsunami from more than 3 hrs away (distant sources) and the propagation of these as national tsunami warnings. This was also intended to cover some regional sources (1-3 hrs of travel time away) in 2016, depending on how rapidly warnings are able to be delivered. In the Wellington region and the Hutt Valley, the first smaller wave arrived in $30 \mathrm{~min}$, which makes this a local-source event for Wellington. There are no guarantees which waves will be the largest in any event, and on this occasion, it was lucky the initial wave was not the largest one.

The national message for warning of local-sourced tsunami is to evacuate immediately on natural warnings, especially after feeling long or strong ground shaking from an earthquake, and not to wait for an official warning (MCDEM, 2017c; see Data and Resources). In the Kaikôura earthquake, the ground shaking lasted at least one minute, but the strength of felt shaking across the Wellington region was variable, especially with many people asleep.

\section{Method}

\section{Design}

The study involved undertaking a community-based survey in Petone and Eastbourne using a citizen science approach to gather data on people's tsunami evacuation behaviors following the Kaikōura earthquake. Citizen science is a collaborative approach to research that involves both scientists and members of the public observing and conducting research (Goodchild, 2007). In this study, the research team included staff and students from Massey University (known as the Joint Centre for Disaster Research [JCDR]) and GNS Science, community residents from Petone, Eastbourne, and the wider Wellington region.

\section{Procedure}

The citizen science approach evolved after a member of the Eastbourne community board contacted staff from the JCDR to discuss the community's tsunami evacuation behavior. For context, a community board advocates community needs and serves as a conduit between local councils and community representatives (Local Government New 
Zealand, 2017; see Data and Resources). Members of JCDR (from Massey University) were then invited to meet with Eastbourne and Petone community board members at the monthly Eastbourne meeting to discuss potential research initiatives related to the Kaikōura tsunami evacuation. Realizing the importance of such a project to understand, improve, and further knowledge about tsunami risk and evacuation, representatives from the Eastbourne and Petone community boards agreed to participate and recruit community members to assist with data collection. As argued by Pocock et al. (2014), people are motivated to contribute to science because of community connection, interest, and a desire to help others.

While collecting data using a citizen science method, for this type of project, minimal training and expertise were required of the volunteers (Goodchild, 2007). This meant that data collection volunteers were given only a verbal briefing and were provided with written instructions about the project and how to approach, engage, and communicate with potential respondents. Surveys were conducted in Petone and Eastbourne over a one-week period between 10 and 18 December 2016. The one-week time frame acted as a form of control to ensure the citizen scientist had a survey collection time boundary.

A range of tactics were used to approach survey respondents. These included canvasing members of the public on the street and going from door to door in residential housing areas. A tsunami survey stall also operated over a 4-hr period at an Eastbourne community fair. Volunteers were also given survey forms to take away to collect data from friends, family, and other community members. Respondents could either fill out the questionnaire themselves or have a citizen scientist read out the questions so the respondents could answer the survey questions verbally and the citizen scientist could fill in the survey.

Using citizen science enabled creative and communityfocused methods of data collection. For instance, one volunteer was a general practitioner at a medical practice who asked patients in her office about their tsunami evacuation behavior; other volunteers rode a water ferry that transported workers across the Wellington Harbour, asking for survey respondents during the trip. This allowed a wider range and a greater number of participants than if the data had been solely collected by a small team of researchers over the same period of time.

It is important to manage citizen science expectations about the outcomes of a project (Pocock et al., 2014). Therefore, with this work, the lead citizen scientists were informed that the survey findings would be disseminated back to community boards and presented in an article such as that produced here.

This research was conducted following the guidelines as outlined in Massey University's Code of Ethics (Project Identification Code: 4000017003).

\section{Materials and Analysis}

The survey questionnaire used in this research was based on the questionnaire used in the project by Dhellemmes et al. (2016) that aimed to assess intended tsunami evacuation behavior at a nonresponse time and provide a long-term benchmark that could be monitored for change related to education, exercises, and real events. The questionnaire had 24 questions that aimed to gather what people were doing at the time of the earthquake, how strong they felt the earthquake was, the duration of shaking, behavior after the earthquake, evacuation behaviors, length of time to take action, where people went, and evacuation points. Demographic data (age, date of birth, and living situation) were also collected.

Data were analyzed using the SPSS statistical software program for the Social Sciences.

\section{Respondents}

Citizen scientists were asked to ensure that surveys only be completed by respondents who were physically present and resided in the Petone or Eastbourne tsunami evacuation zones at the time of the Kaikōura earthquake on 14 November 2016. There were 245 Petone respondents (60\% of the total) and 164 Eastbourne respondents (40\% of the total). The total number of surveys collected from Petone and Eastbourne was 409 . The living situation of the respondents comprised 178 who identified as being a family with children $(97$ Petone and 81 Eastbourne), 126 who identified as being a family without children (80 Petone and 46 Eastbourne), 78 who identified they lived alone (47 Petone and 31 Eastbourne), and 19 who identified as living with nonfamily members (17 Petone and 2 Eastbourne). The sexes of the respondents from both areas included 253 females and 153 males. One respondent identified as gender diverse, and one respondent preferred not to disclose either sex or gender. Of the respondents that identified age, the oldest was $93 \mathrm{yrs}$ old and the youngest 16 yrs old. Respondents were born between 1916 and 2001. The biggest age range of respondents was $40-50$ yrs (109), with only 31 respondents being 21 yrs of age or younger. There were 51 respondents between 30 and $40 \mathrm{yrs}, 72$ between 50 and $60 \mathrm{yrs}, 49$ between 60 and $70 \mathrm{yrs,}$ 47 between 70 and $80 \mathrm{yrs}$, and 19 between 80 and $95 \mathrm{yrs}$.

\section{Results}

The following results represent descriptive statistics on the behaviors reported by people in the Hutt Valley suburbs of Petone and Eastbourne at the time of the Kaikoura earthquake.

\section{Did the Earthquake Wake You?}

The M 7.8 Kaikōura earthquake woke the majority of respondents who were sleeping in Petone and Eastbourne (78\%). About $74 \%$ of the 245 Petone respondents were woken, and $84 \%$ of the 164 Eastbourne respondents were 
woken. Of the total respondents, $18 \%$ reported being awake at the time the earthquake hit, $21 \%$ being Petone respondents, and $15 \%$ Eastbourne respondents. A small number of respondents $(3 \%)$ from both suburbs reported sleeping through the earthquake (5\% Petone and $1 \%$ Eastbourne) (see Fig. 2).

Responses to Earthquake Intensity, Length, and Household Damage

Half of the total respondents from Petone and Eastbourne described experiencing the earthquake as strong to powerful or hard to stand up (51\%), and a further $19 \%$ experienced the earthquake as violent to severe. Only $27 \%$ of all respondents described the earthquake as moderate in that they could still stand up, and only $3 \%$ described it as mild or not felt but unmistakably an earthquake. For a breakdown of data between respondents in Petone and Eastbourne, see Figure 3. Of those who felt the earthquake, the majority reported experiencing the shaking in excess of 1 min. About $40 \%$ of all respondents reported that the earthquake lasted between 60 and $90 \mathrm{~s}$, and another $20 \%$ of all respondents reported the earthquake lasted between $90 \mathrm{~s}$ and $2 \mathrm{~min}$. About $4 \%$ reported that the earthquake lasted more than 2 min. About $60 \%$ of all respondents reported no physical damage to their homes because of the earthquake $(56 \% \mathrm{Pe}$ tone and $66 \%$ Eastbourne); however, of those who had properties that were damaged, $33 \%$ of respondents reported slight damage (36\% Petone and 30\% Eastbourne), $4 \%$ of all respondents reported moderate damage (4\% Petone and 3\% Eastbourne), and $0.5 \%$ of respondents had severe damage (0.4\% Petone and $0.6 \%$ Eastbourne).

What Alerted You to a Possible Tsunami?

When asked what factors warned people of a possible tsunami, $21 \%$ of the total respondents stated that the earthquake (natural warning) alerted them of a possible tsunami. About $17 \%$ of the total respondents reported that other people in the house or family members warned them of a tsunami, $15 \%$ of the total respondents stated that they were warned of a tsunami by community members, $5 \%$ of the total respondents received a warning from an emergency service such as police or fire service, and $45 \%$ of the total respondents said that an official warning from Civil Defence on social media, radio, television, and so on alerted them to the possible tsunami. Some respondents indicated more than one factor warned them.

\section{Evacuation Behavior}

Of the total respondents, $70 \%$ reported evacuating at some stage after the earthquake (79\% of Petone respondents and $56 \%$ of Eastbourne respondents). This is strikingly similar to the intentions of survey responses from Eastbourne residents in 2015, when $65 \%$ intended to evacuate directly from a felt earthquake less than $1 \mathrm{hr}$ tsunami travel time away (Dhellemmes et al., 2016). About $67 \%$ of total respondents reported evacuating because of a possible tsunami, with one respondent describing the long and strong earthquake as the 
reason for evacuating. However, only $11 \%$ of the total respondents cited the earthquake (natural warning) as the main reason for evacuating. About $12 \%$ of all respondents reported the main reason for evacuating was household family members, $9 \%$ of all respondents stated that the main reason was other community members, $2 \%$ of all respondents cited the main reason they evacuated was the emergency services, and $21 \%$ of total respondents evacuated because of an official warning over social media, the radio, or television. Figure 4 provides a breakdown of the reasons why people evacuated.

About $9 \%$ of all respondents reported evacuating twice. The group that evacuated twice, evacuated directly after the earthquake occurred, returned home, and then evacuated again after receiving an official warning via one or more sources, including the Hutt CDEM flood siren. According to the Hutt City Council (2017; see Data and Resources), these sirens aim to alert residents to the potential of serious flooding or other events that could affect the area. They are not dedicated tsunami warnings. After the siren is activated, residents are expected to go to the Hutt City Council emergency status information page on their website or listen to the radio or television to access additional information about the hazard risk.

A small number of the total respondents $(7 \%)$ evacuated immediately after the earthquake without taking any action. The remainder of the total respondents who reported evacuating reported performing a number of actions first; these included gathering life essentials (food and water) (35\%), gathering family members (29\%), calling family and friends (28\%), obtaining further official information $(21 \%)$, discussing action plans with family or other community members (20\%), gathering pets (14\%), assisting others in evacuation (10\%), and collecting valuables (6\%).

Figure 5 compares the percentage of respondents in Petone and Eastbourne that took action before evacuating. About 9\% of the Petone respondents and 4\% of the Eastbourne respondents took no action and evacuated immediately. Only $35 \%$ gathered life essentials in the Petone cohort, which is similar to the 34\% in Eastbourne. As depicted in Figure 5, Eastbourne residents had a slightly lower percentage of respondents who gathered family members $(24 \%$; $33 \%$ Petone). Of those who called family and friends, Eastbourne had a slightly lower number (26\%) than Petone (29\%), and of those who sought official information, Eastbourne was higher with 24\%; Petone was 19\%. About 21\% of Eastbourne respondents reported discussing their action plans with others, and $19 \%$ of Petone respondents discussed action plans. About $10 \%$ of respondents in each area identified helping others evacuate.

It took from 1 to $10 \mathrm{~min}$ for $29 \%$ for all respondents to take their discussed actions, 10 to $30 \mathrm{~min}$ for $16 \%$ of all respondents to take these actions, and 1 to $3 \mathrm{hrs}$ for $11 \%$ of all respondents to take these actions. The 2015 survey of Eastbourne residents found that $62 \%$ of residents expected to take less than 10 min to prepare to evacuate (Dhellemmes et al., 2016).

About $29 \%$ of total respondents did not evacuate (21\% Petone and $42 \%$ Eastbourne). Of those who stated that they did not evacuate, the reasons ranged from getting "mixed 
messages" about the risk of a tsunami to "feeling it was not necessary." Of the respondents who did not evacuate, it was reported that the nonevacuation behavior was because of "feeling safe," that they "had nothing to worry about," or that they "couldn't get out [because] there was too much traffic." Others just "slept through everything." A number of Eastbourne nonevacuees reported living "up a hill" and therefore did not think they were at any risk from a tsunami.

\section{How Did You Evacuate, and Where Did You Go after Evacuating?}

Most respondents located in Petone at the time of the Kaikōura earthquake reported evacuating by car (78\%); only $2 \%$ evacuated on foot. Of the Eastbourne residents who responded, $42 \%$ reported evacuating by car and $15 \%$ by foot. This contrasts with the $22 \%$ of Eastbourne residents surveyed in 2015 who intended to evacuate by car after a felt earthquake (Dhellemmes et al., 2016). From the total respondents in both Petone and Eastbourne, 64\% (260 respondents) evacuated by car, and $7 \%$ (29 respondents) evacuated by foot. Only $4 \%$ of the total respondents said they needed assistance in evacuating. Reasons for assistance ranged from "not being able to drive," "not being able to drive at night," "not being able to walk," and "not being able to walk fast enough." People also reported that they "did not have a car so they travelled with neighbours."

There were a variety of accounts of where people went after they evacuated. The majority of Petone residents went inland from the coast or traveled up to one of the surrounding hill areas to "wait it out." For the majority of Eastbourne residents, traveling to a safe area was easy as Eastbourne has high ground in close proximity. However, $3 \%$ of Eastbourne respondents reported driving along a coastal road from Eastbourne toward Lower Hutt city to evacuate.

\section{Discussion}

This work presents survey data collected by citizen scientists on tsunami warnings and evacuation behavior approximately three and a half weeks after the 2016 M 7.8 Kaikoura earthquake. It is an opportunistic study in that the survey was conducted as quickly as possible after the earthquake to minimize memory effects and to engage respondents while the event was still meaningful to their lives. This study aimed to collect data on actual responses to a tsunami warning, an understudied area; therefore, it was vital to produce knowledge in this domain as efficiently as possible.

Based on official information, an $\mathbf{M} 7.8$ earthquake is among the largest recorded in Aotearoa/New Zealand's history. Because of the epicenter being well inland and the early uncertainty of the earthquake's magnitude, a "no tsunami threat" message was initially issued (Power et al., 2017). It took nearly an hour for a tsunami threat to be officially recognized and a warning to be announced. However, in Aotearoa/New Zealand tsunami evacuation, education advises people not to wait for an official warning, that if people live or are near the coast when an earthquake strikes and the earthquake is experienced as long or strong, people should evacuate to safe ground. This tsunami evacuation message argues that if an earthquake is longer than 1 min or strong enough that people cannot stand up, they need to evacuate immediately (MCDEM, 2017c; see Data and Resources).

Despite the promotion of this tsunami evacuation message, the findings established that of the total that evacuated $37 \%$ did not evacuate within the recommended $10 \mathrm{~min}$ after experiencing a long or strong earthquake. These respondents had no way of knowing that the earthquake was not in the Hikurangi subduction zone or that it would not cause a localsource tsunami which could hit quickly $(<1 \mathrm{hr})$. Only 33\% of the total respondents (34\% Petone and 31\% Eastbourne) evacuated with the recommended 10-min time frame.

That only a small number of respondents evacuated because of the natural earthquake warning is concerning, especially if it is considered that $70 \%$ of the total respondents experienced the earthquake as either strong (hard to stand up) or violent or severe, and that $40 \%$ of the total respondents felt that the earthquake lasted between 60 and $90 \mathrm{~s}$. It is noteworthy that a further $20 \%$ of all respondents reported that the earthquake was between $90 \mathrm{~s}$ and 2 min long.

The nationwide "long or strong, get gone" campaign was launched by the MCDEM in December 2016, and a survey into the effectiveness of the campaign showed that $81 \%$ of respondents knew to evacuate in a tsunami after a long or strong earthquake; however, the reasons people might delay their evacuation were not explored (MCDEM, 2017a, see Data and Resources).

Many respondents stated they were confused directly after the earthquake about tsunami risk and waited for official sources to inform them of a potential tsunami. This was coupled with the fact that some respondents found "mixed messages on the Internet" or "struggled to find Internet info." The mixed messages described may logically include the situation of an initial "no tsunami threat" message followed later by a tsunami warning. People's desire for information to confirm the correct actions to take after an event informs us of the need for more effective tsunami education about when to evacuate based on a natural warning and exercises that target communities such as Petone and Eastbourne.

It is also noteworthy that $9 \%$ of the total respondents evacuated twice. One respondent reported returning home after a first evacuation because of being the "only people" at the evacuation point; this person returned home after the second evacuation because of the official "all-clear" message. Another respondent reported evacuating after the natural earthquake warning but returned home when no tsunami warning had been raised; however, this person evacuated again when the warning was raised hours later. This shows that people who evacuated because of the natural warning may lack knowledge of tsunami risk and what to do after evacuating. It also demonstrates that people can be unsure 
about their behavior when others do not follow the same behavior. In her work on evacuation behavior, Boer (2005) describes copying the behaviors of others in an emergency as a herd instinct. It is officially advised that people should not return home for at least $24 \mathrm{hrs}$ (or longer) after evacuating unless given a message by official sources that it is safe to return home (MCDEM, 2017c, see Data and Resources). These findings support the Gill et al. (2015) claim that Aotearoa/New Zealand needs to improve self-evacuation behavior for warning times under $1 \mathrm{hr}$. There was a delay between the actual earthquake event and the official warning to evacuate because of the complexity of the 21 surface fault ruptures and the earthquake epicenter being inland. It also highlights the impact of the absence of a 24-hr warning system in Aotearoa/New Zealand.

The survey responses demonstrated that the majority of all respondents evacuated by car (64\%). This tsunami evacuation behavior disregarded tsunami evacuation advice, which states that people should walk or use a bicycle to evacuate where possible. It is advised that people should only drive when absolutely necessary (MCDEM, 2017c; see Data and Resources) because of traffic congestion and the panic that people can experience. One of the respondents reported that she or he did not evacuate as she or he "couldn't get out, too much traffic," another reported trying to "avoid traffic as friends got stuck on [the] Wainui Hill," and another respondent said there "were so many cars speeding down the road and up the hill that they were worried the "overbridge would come down." It is important to note that Petone residents need to travel up to $\sim 4 \mathrm{~km}$ (for more information, see Google, 2017; see Data and Resources) to get to a safe location. This could contribute to the use of car for evacuation.

That a majority of respondents used their cars mimics the results found by Johnston et al. (2003) in which most people also stated they preferred to use their vehicles rather than evacuate by foot. It also corresponds to findings from a study looking at evacuation behavior after the 2011 Japan earthquake. Of the 256 surveyed evacuees, $65 \%$ reported evacuating by car because they thought they could evacuate faster. About $36 \%$ of these evacuees were caught in a traffic jams (Murakami et al., 2012).

\section{Limitations}

A number of limitations have an impact on this study. For example, although citizen science is a growing field that enables larger sample sizes with less resourcing and specific community engagement while valuing a bottomup research approach, it does not adhere to the rigor of pure scientific methods. In this sense, there was no control over the way in which survey questions were asked or responses were recorded. This can mean that research methods could be skewing the results. Furthermore, there could be a natural bias in the samples in that people who evacuated were more likely to respond to the survey. It was also unclear if respondents understood if they lived in the red or yellow tsunami zones and how that impacted their evacuation behavior.

\section{Future Research}

This study highlights the importance of ongoing research and knowledge acquisition in the area of tsunami evacuation behavior. It would be pertinent to ascertain how the Petone and Eastbourne communities now understand and perceive official siren warnings for tsunami in their areas and if there is an expectation that a siren would be used as a warning in the future. It would also be useful to explore the views of the Hutt City Council, a legislative body that governs the Lower Hutt city, in regard to how the council perceived the use of the flood warning siren went on the night of the event, if the council intended to use them in the future, and if the council had conducted any research with communities in its areas about the flood warning after the Kaikōura earthquake. Understanding how the Hutt City Council is currently informing its constituents about tsunami warnings or evacuation behavior would enable more efficient and targeted education strategies. Furthermore, research that explores where people sourced official information after the Kaikoura earthquake, what sources were available at the time, how these information sources were accessed, and how accurate the information was could better enable information dissemination strategies in future events.

It is also necessary to understand more about what people defined as life essentials and how many had prepared evacuation kits at the time of the earthquakes, what was in these kits, and whether they took these kits with them when they evacuated. Understanding exactly what people thought was important to take with them when they evacuated and comparing it with what is officially advised would tell us how people are engaging with official information about preparedness behavior and if the information is useful. It could also indicate people's ability to prepare. Previous research by Blake et al. (2017) proposed that preparedness behavior is limited for people living in lower socioeconomic conditions because obtaining the necessary suggested items required in a preparedness kit is not a priority (for more information on preparedness items, see WREMO, 2018). It is also imperative to understand if evacuation experiences during the Kaikōura earthquake have changed people's tsunami behavior or preparedness planning and how such events have had an impact on the way in which a community might function and support collective or social emergency management planning.

\section{Conclusion}

This study aimed to understand tsunami evacuation behavior after a tsunami event. It showcases the communities of Eastbourne and Petone who had tsunami evacuation maps and prior national and local education on evacuating on long 
or strong ground shaking. The Kaikōura earthquake was a local source to Wellington (first-wave arrival within $1 \mathrm{hr}$; in this case, $30 \mathrm{~min}$ ) but produced a tsunami with largest waves arriving between 1 and $5 \mathrm{hrs}$ postearthquake.

The majority of respondents were woken by the earthquake (78\%), and a further $18 \%$ were already awoken. The earthquake was longer and stronger than the threshold for tsunami evacuation in tsunami education materials. The shaking was felt to be longer than 1 min by the majority and at least strong by $7 \%$, either of which is the threshold for natural warning evacuation.

The proportion of people who evacuated, although being the majority, was substantially less than in Japan in 2011 (95\% survival and a rough proxy for the evacuation rate), and the majority did not evacuate as quickly as guidelines suggested they should. About $79 \%$ of respondents evacuated at some stage, but only $11 \%$ cited the earthquake as the main reason. Only 33\% evacuated within the prescribed minimum $10 \mathrm{~min}$ despite not knowing then whether any generated tsunami was coming from this 10 min travel-time source or farther away. Additionally, 55\% took longer than $30 \mathrm{~min}$ to prepare to evacuate. About $9 \%$ of the total respondents evacuated twice, indicating they did not stay away long enough to avoid potentially large waves. The majority of people who evacuated used cars, leading to prohibitive traffic congestion.

Dhellemmes et al. (2016) surveyed residents of Eastbourne's intentions in a hypothetical long or strong felt earthquake less than $1 \mathrm{hr}$ of tsunami travel time away. A similar proportion of people actually evacuated in response to the Kaikōura earthquake, as had intended to evacuate in 2015, but they delayed their evacuation longer than expected, and more used their cars than anticipated. This indicates that intention to evacuate is a surprisingly accurate proxy for actual evacuation and could be used as a longitudinal indicator to gauge effectiveness of interventions (education, exercises, and so on) in the future. Further work is planned to qualitatively explore the differences in response between the two communities, which have notably different socioeconomic profiles.

As a result of confusion as to the warning of the tsunami, two initiatives were fast tracked by central government in 2017: Cell broadcast (Emergency Mobile Alerts) to alert people via mobile phones was implemented (MCDEM, 2017b, see Data and Resources), and enhancements to GeoNet (New Zealand Government, 2017, see Data and Resources), the national geohazard monitoring system run by GNS Science, were funded to provide primary monitoring and evaluation of tsunami and 24/7 warning center capability.

This study highlights the need to further enhance community capacity to respond appropriately to both natural and agency-generated tsunami warnings to ensure safety for people and communities and reduce confusion between these two sources of warning. This may encompass aspects such as better information and public education in conjunction with annual tsunami evacuation exercises.

\section{Data and Resources}

The data were collected by the authors and citizen volunteers. Data are stored confidentially as outlined in Massey University's Code of Ethics (Project Identification Code: 4000017003). Additional resources used are as follows: Hutt City Council (2017), Civil Defence Sirens, retrieved from http://www.huttcity.govt.nz/Services/Emergency-management/ Civil-Defence-Sirens/, last accessed October 2016; Google (2017), Google maps, retrieved from https://www.google.co. $\mathrm{nz} / \mathrm{maps} / \mathrm{dir} /$ Petone+Foreshore+Playground,+Petone,+Lower + Hutt+5012/Ewen+Bridge, + Alicetown, + Lower+Hutt+5010/ @-41.2218205,174.8832084,15z/data=!3m1!4b1!4m13!4m12! 1m5!1m1!1s0x6d38abc8c457eb81:0x49ff3cfce1d4ad11!2m2! 1d174.8898457!2d-41.2321167!1m5!1m1!1s0x6d38abab53fd 5077:0x62b45300f041654a!2m2!1d174.8973041!2d-41.2129531, last accessed October 2016; GNS Science Te Pū Ao (2017), Cook Strait fault map, retrieved from https://www.gns.cri. nz/Home/IOF/It-s-Our-Fault/Cook-Strait-fault-map, last accessed October 2016; Local Government New Zealand (2017), Community boards, retrieved from http://www.lgnz.co.nz/ nzs-local-government/community-boards, last accessed October 2016; Ministry of Civil Defence and Emergency Management (MCDEM) (2017a), Get Ready Get Thru campaign evaluation 2017, retrieved from https://www.civildefence. govt.nz/cdem-sector/public-education/research-and-evaluation/ get-ready-get-thru-campaign-evaluation/, last accessed October 2016; MCDEM (2017b), Emergency mobile alert, retrieved from http://www.civildefence.govt.nz/get-ready/civil-defenceemergency-management-alerts-and-warnings/cell-broadcastalerting/ (last accessed September 2017); MCDEM (2017c), Get tsunami ready, retrieved from http://www.civildefence.govt .nz/get-tsunami-ready/; New Zealand Government (2017), \$3 million boost for natural hazards monitoring, retrieved from https://www.beehive.govt.nz/release/3-million-boost-naturalhazards-monitoring (last accessed September 2017); and Statistics New Zealand (2013), 2013 Census map-QuickStats about a place, retrieved from http://archive.stats.govt.nz/StatsMaps/Home/ People\%20and\%20households/2013-census-quickstats-about-aplace-map.aspx (last accessed April 2018).

\section{Acknowledgments}

The authors would like to acknowledge the following funding sources in undertaking this research: Resilience to Nature's Challenges National Science Challenge and the Strategic Science Investment Fund. The authors would also like to acknowledge the support of Virginia Horrocks, Pam Hanna, the communities of Petone and Eastbourne, and the volunteers who assisted.

\section{References}

Bell, R., C. Holden, W. Power, X. Wang, and G. Downes (2014). Hikurangi margin tsunami earthquake generated by slow seismic rupture over a subducted seamount, Earth Planet. Sci. Lett. 397, 1-9.

Bird, D. K., C. Chagué-Goff, and A. Gero (2011). Human response to extreme events: A review of three post-tsunami disaster case studies, Aust. Geogr. 42, no. 3, 225-239, doi: 10.1080/00049182.2011.595670. 
Blake, D., J. Marlowe, and D. Johnston (2017). Get prepared: Discourse for the privileged? Int. J. Disast. Risk Reduct. 283-288, doi: 10.1016/ j.ijdrr.2017.09.012.

Boer, L. C. (2005). Getting passengers out-Evacuation behaviours, in Rail Human Factors-Supporting the Integrated Railway, J. Wilson, B. Norris, T. Clarke, and A. Mills (Editors), Routledge, New York, New York, 462-472.

Couling, M. (2013). Tsunami risk perception and preparedness on the east coast of New Zealand during the 2009 Samoan tsunami warning, Nat. Hazards 71, 973-986.

Currie, C. S., J. Enjamio, D. Girardo, C. Hensel, G. Leonard, and D. Johnston (2014). Tsunami awareness and preparedness in the Greater Wellington Region, Institute of Geological \& Nuclear Sciences Report, 2014/10, $83 \mathrm{pp}$

Dhellemmes, A., G. S. Leonard, and D. Johnston (2016). Tsunami awareness and preparedness on the East Coast of New Zealand's North Island, Institute of Geological \& Nuclear Sciences Report 2016/20, 81 pp.

Fraser, S. A., E. H. Doyle, K. C. Wright, S. H. Potter, J. McClure, D. M. Johnston, G. S. Leonard, M. A. Coomer, J. S. Becker, and S. Johal (2016). Tsunami response behaviour during the following two localsources earthquakes in Wellington, New Zealand, Int. J. Disast. Risk Reduct. 16, 123-133, doi: 10.1016/j.ijdrr.2016.02.008.

Gill, D., P. Clough, and T. Webb (2015). Tsunami risk facing New Zealand, NZIER Report to the Earthquake Commission, New Zealand Institute of Economic Research, Wellington, New Zealand.

Goodchild, M. F. (2007). Citizens as sensors: The world of volunteered geography, GeoJournal 69, 211-222, doi: 10.1007/s10708-007-9111-y.

Gregg, C. E., B. F. Houghton, D. Paton, R. Lachman, J. Lachman, D. M. Johnston, and S. Wongbusarakum (2006). Natural warning signs of tsunamis: Human sensory experience and response to the 2004 Great Sumatra earthquake and tsunami in Thailand, Earthq. Spectra 22, no. S3, doi: 10.1193/1.2206791.

Horspool, N., W. J. Cousins, and W. L. Power (2015). Review of Tsunami Risk Facing New Zealand: A 2015 Update, GNS Science, Lower Hutt, New Zealand.

Johnston, D., J. Becker, J. McClure, D. Paton, S. K. McBride, K. C. Wright, G. Leonard, and M. Hughes (2013). Community understanding of, and preparedness for, earthquake and tsunami risk Wellington, New Zealand, in Cities at Risk: Living with Perils in the 21st Century, H. Joffe, T. Rossetto, and J. Adams (Editors), Advances in Natural and Technological Hazards Research, Vol. 33, Springer, Dordrecht, The Netherlands, 131-148.

Johnston, D., R. Pettersson, G. Downes, D. Paton, G. Leonard, K. Pishief, and R. Bell (2008). Developing an effective tsunami warning system: Lessons from the 1960 Chile earthquake tsunami for New Zealand coastal communities, Kōtuitui 3, no. 2, 105-120, doi: 10.1080/ 1177083X.2008.9522436.

Johnston, D. M., G. S. Leonard, R. Bell, C. Stewart, M. Hickman, J. Thomson, J. Kerr, and P. Glassey (2003). Tabulated results of the 2003 national coastal community survey, Institute of Geological \& Nuclear Sciences science report 2003/35, Institute of Geological and Nuclear Sciences Limited, Lower Hutt, New Zealand, 118 p.

Lindell, M. K., C. S. Prater, C. E. Gregg, E. J. I. Apatu, S. Huang, and H. C. Wu (2015). Households' immediate responses to the 2009 American Samoa earthquake and tsunami, Int. J. Disast. Risk Reduct. 12, 328-340, doi: 10.1016/j.ijdrr.2015.03.003.

Ministry of Civil Defence and Emergency Management (MCDEM) (2016). Tsunami Evacuation Zones: Director's Guideline for Civil Defence Emergency Management Groups [DGL08/16], MCDEM, Wellington, New Zealand, 39 pp.

Ministry of Civil Defence and Emergency Management (MCDEM) (2017a). Kaikōura Earthquake and Tsunami: 14 November 2016 Post Event Report (MCDEM Response), Ministry of Civil Defence and Emergency Management, Wellington, New Zealand, 22 pp.
Ministry of Civil Defence and Emergency Management (MCDEM) (2017b). Tsunami Advisory and Warning. MCDEM Supporting Plan [SP 01/17], revised April 2017, MCDEM, Wellington, New Zealand, available at http://www.civildefence.govt.nz/cdem-sector/cdem-framework/ guidelines/national-tsunami-advisory-and-warning-plan/ (last accessed April 2017).

Murakami, H., K. Takimoto, and A. Pomonis (2012). Tsunami evacuation process and human loss distribution in the 2011 Great East Japan earthquake: A case study of Natori City, Miyagi Prefecture, paper presented at the Fifteenth World Congress on Earthquake Engineering, Lisbon, Portugal, 24-28 September 2012.

Pocock, M. J. O., D. S. Chapman, L. J. Sheppard, and H. E. Roy (2014). Choosing and Using Citizen Science: A Guide to When and How to Use Citizen Science to Monitor Biodiversity and the Environment, available at http://nora.nerc.ac.uk/id/eprint/510644/1/N510644CR .pdf (last accessed April 2018).

Power, W. (2013). Review of tsunami hazard in New Zealand (2013 update), GNS Science Consultancy Report 2013/131.

Power, W., K. Clark, D. N. King, J. Borrero, J. Howarth, E. M. Lane, D. Goring, J. Goff, C. Chagué-Goff, J. Williams, C. Reid, et al. (2017). Tsunami runup and tide-gauge observations from the 14 November 2016 M7.8 Kaikōura earthquake, New Zealand, Pure Appl. Geophys. 174, no. 7, 2457-2473, doi: 10.1007/s00024-017-1566-2.

Suzuki, I., and Y. Kaneko (2013). Japan's Disaster Governance: How Was the 3.11 Crisis Managed? Springer, New York, New York.

Ullah, A. K. M. A. (2011). Displaced, disabled and disturbed: Narratives of trauma and resilience among Acehnese survivors of the 2004 tsunami, NTS-Asia Research Paper No. 7, RSIS Centre for Non-Traditional Security (NTS) Studies for NTS-Asia, Singapore.

Wellington City Council (2017). Draft Wellington Region Natural Hazards Management Strategy February 2017, available at http:/infocouncil .huttcity.govt.nz/Open/2017/02/PRC_27022017_ATT_2383_EXCLUDED .htm (last accessed October 2016).

Wellington Region Emergency Management Office (WREMO) (2018). Earthquake Preparedness Guide, Wellington Region Emergency Management Office, available at https://getprepared.nz/personal-preparedness/guide/ (last accessed October 2016).

Woods, R. J., S. K. McBride, L. M. Wotherspoon, S. Beavan, S. H. Potter, D. M. Johnston, T. Wilson, D. Brunsdon, E. S. Grace, H. Brackley, et al. (2017). Science to emergency management response: Kaikōura earthquakes 2016, Bull. New Zeal. Soc. Earthq. Eng. 50, no. 2, 329-337.

Joint Centre for Disaster Research

Massey University

P.O. Box 756

Wellington 6140

Aotearoa/New Zealand

d.blake@massey.ac.nz

(D.B., D.J., L.M.)

Joint Centre for Disaster Research

GNS Science

P.O. Box 30368

Lower Hutt 5010

Aotearoa/New Zealand

(G.L., J.B.)

Manuscript received 4 October 2017; Published Online 1 May 2018; Corrected Online 14 May 2018 